\title{
Jurnal Teknologi Sistem Informasi dan Aplikasi Vol. 3, No. 3, Juli 2020
}

Available online at http://openjournal.unpam.ac.id/index.php/JTSI

\begin{abstract}
Alamat Redaksi
Universitas Pamulang - Kampus Viktor lantai 6

Program Studi Teknik Informatika

Jalan Raya Puspitek No. 46 Buaran, Serpong, Tangerang Selatan, Banten, Indonesia

Telp./Fax. (021) 7412566
\end{abstract}

\section{Penerbitan:}

Terbit 4 kali dalam satu tahun, setiap bulan Januari, April, Juli, dan Oktober

\section{Penerbit:}

Program Studi Teknik Informatika Universitas Pamulang

http://informatika.unpam.ac.id 


\section{Susunan Dewan Redaksi Jurnal Teknologi Sistem Informasi dan Aplikasi}

\section{Pemimpin Redaksi}

Aries Saifudin, M.Kom., Universitas Pamulang, Indonesia

\section{Tim Reviewer:}

1. Achmad Udin Zailani, M.Kom., Universitas Pamulang, Indonesia

2. Ahmad Fikri Zulfikar, M.Kom., Universitas Pamulang, Indonesia

3. Angga Aditya Permana, M.Kom., M.M., Universitas Muhammadiyah Tangerang, Indonesia

4. Arman Syah Putra, M.M., M.Kom., STMIK Insan Pembangunan, Indonesia

5. Dodick Zulaimi Sudirman, M.Kom., Universitas Bina Nusantara, Indonesia

6. Irpan Kusyadi, M.Kom., Universitas Pamulang, Indonesia

7. Joko Priambodo, M.M., M.Kom., Universitas Pamulang, Indonesia

8. Joko Riyanto, M.Kom., Universitas Pamulang, Indonesia

9. Kecitaan Harefa, M.Kom., Universitas Pamulang, Indonesia

10. Maniah, M.Kom., Politeknik Pos Indonesia, Indonesia

11. Maulana Ardhiansyah, M.Kom., Universitas Pamulang, Indonesia

12. Melyani, M.M., Universitas Bina Sarana Informatika, Indonesia

13. Rachmat Destriana, M.Kom., Universitas Muhammadiyah Tangerang, Indonesia

14. Riki, M.Kom., Universitas Buddhi Dharma, Indonesia

15. Rinna Rachmatika, M.Kom., Universitas Pamulang, Indonesia

16. Shandi Noris, M.Kom., Universitas Pamulang, Indonesia

17. Sri Mulyati, M.Kom., Universitas Pamulang, Indonesia

18. Sukirman, M.T., Universitas Muhammadiyah Surakarta, Indonesia

19. Syepry Maulana Husain, M.T.I., Universitas Muhammadiyah Tangerang, Indonesia

20. T. Husain, M.M.S.I., M.I.Kom., M.Ak., STMIK Widuri, Jakarta, Indonesia

\section{Tim Editor:}

1. Analekta Tiara Perdana, M.Si., Universitas Al-azhar Indonesia, Indonesia

2. Ari Irawan, M.Kom., Tanri Abeng University Jakarta, Indonesia

3. Farida Nurlaila, M.Kom., Universitas Pamulang, Indonesia

4. Niki Ratama, M.Kom., Universitas Pamulang, Indonesia

5. Normalisa, M.Kom., Universitas Pamulang, Indonesia

6. Rohmat Taufiq, M.Kom., Universitas Muhammadiyah Tangerang, Indonesia

7. Samsoni, M.Kom., Universitas Pamulang, Indonesia

8. Teti Desyani, M.Kom., Universitas Pamulang, Indonesia

9. Wasis Haryono, M.Kom., Universitas Pamulang, Indonesia

10. Winanti, M.Kom., STMIK Insan Pembangunan, Indonesia

11. Yulianti, M.Kom., Universitas Pamulang, Indonesia

\section{Asisten Editor:}

1. Fajar Kurniawan, S.Kom., Universitas Pamulang, Indonesia

2. Desti Juwita Sari, S.Kom., Universitas Pamulang, Indonesia 


\section{Kata Pengantar}

Puji syukur kehadirat Allah S.W.T. yang telah melimpahkan segala rahmat dan karunia-Nya, sehingga pengelola Jurnal Teknologi Sistem Informasi dan Aplikasi dapat mempublikasikan terbitan volume 3 nomor 3. Pengelola Jurnal Teknologi Sistem Informasi dan Aplikasi menyadari bahwa pengelolaan jurnal ini belum sempurna, kami akan selalu melakukan perbaikan untuk menuju kesempurnaan. Kami terbuka terhadap kritik dan saran untuk perbaikan pengelolaan jurnal ini.

Pengelola jurnal menyadari bahwa pengelolaan jurnal ini takkan terwujud tanpa bantuan, bimbingan, dan dorongan dari beberapa pihak. Kami sebagai pengelola mengucapkan banyak terima kasih kepada:

1. Bapak Dr. (HC) Drs. H. Darsono, selaku Ketua Yayasan Sasmita Jaya.

2. Bapak Dr. H. Dayat Hidayat, M.M., selaku Rektor Universitas Pamulang

3. Bapak Dr. Ali Maddinsyah, S.E., M.M, selaku Ketua LPPM Universitas Pamulang

4. Bapak Syaiful Bakhri, S.T., M.Eng.Sc., Ph.D., selaku Dekan Fakultas Teknik Universitas Pamulang

5. Bapak Dr. Ir. Sewaka, M.M., selaku Ketua Program Studi Teknik Informatika Universitas Pamulang

6. Bapak dan Ibu penulis yang telah mengirimkan artikelnya untuk dipublikasi di Jurnal Teknologi Sistem Informasi dan Aplikasi

Semoga Allah S.W.T. selalu membalas kebaikan dan mencurahkan hidayah serta taufik-Nya kepada kita semua.

Aamiin.

Tangerang Selatan, Juli 2020

Dewan Redaksi 


\section{Daftar Isi}

Halaman Identitas i Susunan Dewan Redaksi Jurnal Teknologi Sistem Informasi dan Aplikasi .....................................ii

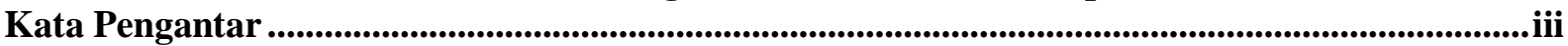
Daftar Isi

Pengujian Black Box pada Aplikasi Verifikasi Data Nasabah dengan Menggunakan Metode Boundary Value Analysis 119-124

Lailan Cipta Hermawan, Moh. Rizki Mubarok, Hidayat Mairudin, Ahmad Mahdiyan, Yulianti Yulianti

Rancang Bangun Sistem Pakar dengan Metode Forward Chaining untuk Rekomendasi Pariwisata di Labuan Bajo Menggunakan iOS Platform 125-131

Leonardo Jeffry, Rinabi Tanamal

Teknik Pengujian Equivalence Partions untuk Pengujian Aplikasi Sistem Penunjang Keputusan Pegawai Terbaik Menggunakan Black Box 132-137

Ahmad Zuhair, Farhan Khadafi, Achmad Muzakih Andriansyah, Bayu Saputra, Aries Saifudin

Implementasi Pengujian Black Box menggunakan Teknik Equivalents Partitions pada Aplikasi Pendaftaran Commuter Line Berbasis Web 138-143

M. Diky Oktafian, M. Azi Haetami, M. Jibril, Reyhan Said, Teti Desyani

Pengujian Aplikasi Pemesanan Tiket Kereta berbasis Website Menggunakan Metode Black Box dengan Teknik Equivalence Partitioning ... 144-149 Riro Bregas Trengginaz, Ade Yusup, Muhammad Ruhul Jihad, Daniel Sovian Sunyoto, Yulianti Yulianti

Pengujian Black Box pada Aplikasi Perpustakaan Menggunakan Teknik Equivalence Partitions Bayu Aji Priyaungga, Dwi Bayu Aji, Mukron Syahroni, Nurul Tri Sukma Aji, Aries Saifudin 150-157

Analisis dan Desain Sistem Pengambilan Keputusan Pengangkatan Karyawan Tetap di PT. Aerofood ACS . 158-164

Rohmat Taufiq, Rachmad Taufiq Prasetyo, Dadang Yusuf

Pengujian Black Box pada Sistem Informasi Praktek Kerja Industri (PRAKERIN) dengan menggunakan Metode Boundary Value Analysis

Muhammad Indra Rizaldi, Sandi Ramadhan, Mochammad Noor Holik Majid, Yulianti Yulianti

Implementasi Teknik Equivalence Partitions untuk Pengujian Black Box pada Sistem Informasi DAPODIKDASMEN 171-177

Alvin Pratama Putra, Noviar Nurdin, Rio Valentino Rondonuwu, Irpan Kusyadi

Implementasi Teknik Equivalence Partitioning pada Pengujian Aplikasi E-learning Berbasis Web 178-184

Andrian Agustian, Imas Andriyani, Sita Khoerunisa, Adjie Pangestu, Aries Saifudin 